\title{
Assessing livelihood impacts of cage based fish fingerlings production on Adivasi households in north-east and north-west Bangladesh
}

\author{
N. Gupta and M. M. Haque \\ Department of Aquaculture, Bangladesh Agricultural University, Mymensingh-2202, Bangladesh. \\ Email: nipa_hstu@yahoo.com
}

\begin{abstract}
In Bangladesh, Adivasi, the indigenous people are of the poorest sections of the society due to their vulnerable livelihoods with lack of resources. Cage based fish fingerling production (CBFFP) was promoted with Adivasi households in the north-east and north-west regions of Bangladesh. A structured questionnaire based survey was conducted with a sample size of 150 CBFFP adopting households to assess the livelihood impacts of CBFFP on the Adivasi households. Geographically, the study represents Sherpur and Netrakona districts from north-east and Dinajpur, Rangpur, and Joypurhat districts from north-west regions of Bangladesh. In terms of socio-economic characteristics, the average household size of Adivasi households was $4.21 \pm 1.28$ with day labour (40\%) based primary occupation. Majority (64\%) of households heads were found illiterate and the remaining with low level education attainment. Most of the Adivasi households depended on a single person's (household head) income. The average size of ponds in which the cages were set was about $1.2 \pm 1.4$ hectare with the depth of $1.5-3 \mathrm{~m}$. The cage provided with Adivasi farmer was of $1 \mathrm{~m}^{3}$ in size and made of locally available materials, mainly bamboo made frame, net and plastic bottles as floats. The average cost of a cage construction was about BDT 400 \pm 85.2 (USD 5.71 \pm 1.2 ). The fry of tilapia (Oreochromis niloticus), silver carp (Hypophthalmichthys molitrix), rui (Labeo rohita), mrigal (Cirrhinus cirrhosus), bighead carp (Aristichthys nobilis), common carp (Cyprinus carpio), Thai sarpunti (Barbonymus gonionotus) were stocked in the cages for fingerling production. The average stocking density was about $875 \pm 507$ fry/cage (about $3.4 \mathrm{~cm}$ in length). In average, fingerling production cost was about BDT 268 $\pm 129.2 / \mathrm{cage}$ (USD $3.83 \pm 1.8 /$ cage) and selling value was about BDT $431 \pm 509.1 /$ cage (USD 6.16 $\pm 7.2 /$ cage). The major impacts of CBFFP include increased household level income (1.7\%), use of this income to buy livestock for rearing further. Moreover, CBFFP impacted positively on other aspects of livelihoods such as purchasing food in lean period, saving money and paying credit. The large size fingerlings produced in the cages were used as food fish for household level consumption. The main constrains of Adivasi households to adopt CBFFP were poaching of fish from cages and variable access to ponds for cage installation.
\end{abstract}

Keywords: Adivasi, Socio-economics, Cage culture, Livelihoods, Bangladesh

\section{Introduction}

Aquaculture contributes $55 \%$ of total inland fish production using only $11 \%$ of the total inland water resources (DoF, 2009). Over the last three decades, aquaculture has been developed as the fastest growing food producing sector in the world playing an important role in poverty alleviation. In 2009, the total fish production of Bangladesh was 2.7 million MT of which 2.1 million MT was derived from inland aquaculture (DoF, 2010). Such level of production is also contributing to global production, thus aquaculture production is expected to reach upto 65.1 million MT in 2030 in the world (Verdegem et al., 2006).

In the developing countries like Bangladesh, aquaculture practices have subtle relationships with poverty. Now-a-days, in most of the rural areas in the world especially in the Asian countries, poverty and malnutrition are wide spread among rural people under population pressure. It is estimated that about $70 \%$ of the population are living in the rural areas (Edward, 2000). Therefore, poverty alleviation should be considered as an important issue of rural development in which the first requirement is to satisfy the basic needs of the poor. For this, it is essential to have an adequate production of food to meet the basic nutritional requirement of the rural poor. In this respect, aquaculture plays a vital role to supply animal protein as well as to contribute to the food security. Furthermore, it provides employment opportunities and generates foreign currency which have broader impacts on social and economic development (Haque, 2007). 
The prerequisite of pond based aquaculture is the availability of quality seed in the rural areas of Bangladesh. Availability of quality large size fish fingerlings in time can make considerable impacts on uptaking aquaculture technologies among rural people. Producing large size fingerlings available in the remote places by natural breeding or nursing fry without installation of fish hatcheries, is conceptualized as decentralized fish seed production strategy (Haque, 2007). Among several options of decentralized fish seed production, cage based fish fingerlings production could be an important option to make a sustainable supply of fish seed to remote places (Haque, 2007). Such way of seed production and its availability in remote areas is critical for commercially important and faster growing fish species e.g. tilapia, silver carp etc.

Among the poor, indigenous ethnic minorities living in clusters in different parts of the country are commonly known as Adivasi, who are vulnerable and far from the mainstream development in Bangladesh (Kamal et al., 2003). They comprise with 45 distinct communities with an estimated population of 2 million people living in the margin on Bangladesh territory. The increasing trend of population growth and decreasing trend of natural resources have negatively affected Adivasi's traditional livelihoods of hunting and gathering of foods from wetlands. Although they are the origin of the country but they are neglected and deprived from the very beginning. However, there is considerable potential to develop underutilized assets including the potential of 'human capital' i.e. develop Adivasi's ability to generate an income from their own resources. Decentralized fish fingerlings production in cages could be a practical option for involvement of rural poor for wider social development. With this view of livelihoods improvement of Adivasi households, CBFFP was promoted by NGO in ponds in north-east and northwest regions of Bangladesh. In this context, the objective of this study was to assess the impacts of cage based fish fingerlings production on livelihoods of Adivasi households.

\section{Materials and Methods}

This study was conducted in five (5) districts in north-east and north-west regions of Bangladesh. In north-east, the selected districts were Sherpur and Netrakona and in north-west, the selected districts were Dinajpur, Rangpur and Joypurhat, under this study (Fig. 1). Several villages were selected under these districts for this study. The selected villages have large number of Adivasi households who adopted cage farming compared to other villages. A sample size of 150 cage adopting Adivasi households was selected randomly from the above districts.

Data were collected through questionnaire survey for three months from July to September, 2009. The questionnaire was designed to characterize cage adopting households with socio-economic characteristics and to get the insights into livelihoods impacts of CBFFP on farming households. The questionnaire was tested initially and finalized after repeated corrections. The collected data were entered into the database software MS-Access and analyzed using SPSS (version 11.5). The findings are presented in tabular and graphical forms.

\section{Results and Discussion}

\section{General socio-economic characteristics of Adivasi households}

The average Adivasi household size was $4.21 \pm 1.28$, which is very closed to the national average of 4.89 (BBS, 2004). The total number of family members ranged from 1 to 9 . Their household income was low reflecting that four-member households cannot meet their basic needs properly. Some of the households were larger indicating that the households had to bear huge maintenance cost with their limited household income. 


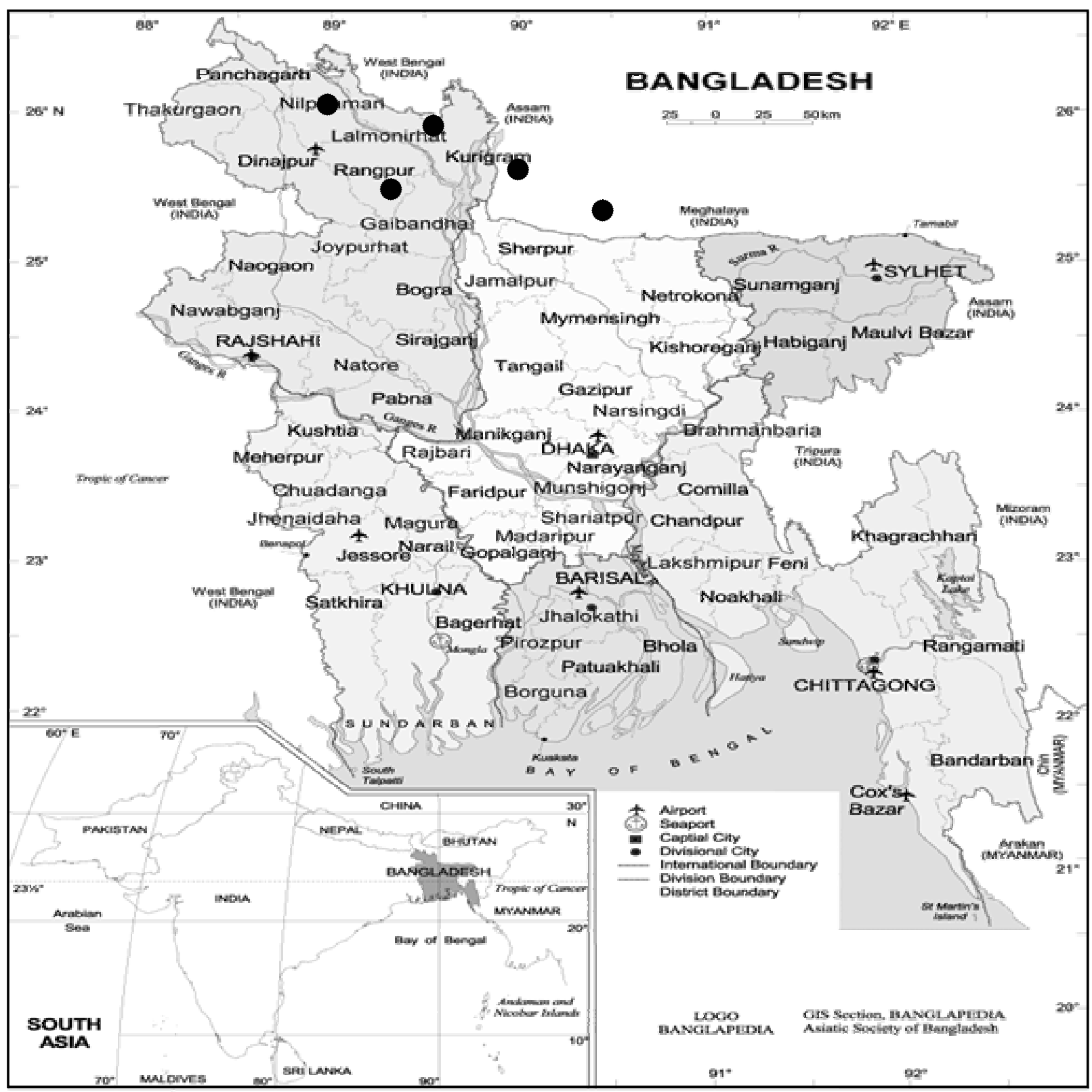

Fig. 1. Map showing the study area in north-east and north-west Bangladesh 
The household head of Adivasi households involved in cage based fingerlings production represented a wider age distribution from minimum 19 to maximum 80 years. Average age of the household heads was around $45(44.57 \pm 12.445)$ years. About $64 \%$ of household heads were illiterate, $15.3 \%$ had primary and $19.3 \%$ had secondary level of education and only 1.3\% had higher secondary level of education (Table 1). This indicated lower level of literacy than the national adult literacy level of $54.8 \%$ (BANBEIS, 2010) which further suggested that they are poor by lacking of formal education. Learning mother tongue, Adivasi children get difficulty in school while teaching is done with mainstream (Bengali) language. In the context of lacking formal education, hands on operation of cage based fingerling production made an appropriate learning path for Adivasi people irrespective of gender and age which may be an indicator of sustainable livelihood improvement (Haque et al., 2010).

Table 1. Level of education of household heads of cage adopting Adivasi households

\begin{tabular}{|l|l|}
\hline Education attainment & Percentage (\%) of household heads \\
\hline Above secondary & 1.3 \\
\hline Class VI-X (secondary) & 19.3 \\
\hline Class I-V (primary) & 15.3 \\
\hline Illiterate & 64.0 \\
\hline
\end{tabular}

About $40 \%$ of cage adopting farmer's occupations were day labour and agriculture as the main occupations (Table 2) followed by van/rickshaw puller (7\%). Hallman et al. (2003) stated that engaging in agriculture has been recognized as a primary livelihood strategy of the majority of the households in Bangladesh. In most cases, day labour was also secondary occupation depicting Adivasi people worked in the agricultural field living in hardship. Many of them had no secondary occupation (45\%) indicating their vulnerable economic status. Only $7 \%$ of the households involved themselves in fish culture because they do not have their own ponds. In this context, cage based fish fingerlings production could be a noble opportunity to enhance their income.

Table 2. Category of occupation of household heads of cage adopting Adivasi households

\begin{tabular}{|l|c|c|c|c|c|c|}
\hline \multirow{2}{*}{$\begin{array}{l}\text { Occupation } \\
\text { category }\end{array}$} & \multicolumn{5}{|c|}{ Percentage (\%) of occupation by different category } \\
\cline { 2 - 7 } & Day labour & Agriculture & Van/Rickshaw puller & Fishing & Other occupation & None \\
\hline $\begin{array}{l}\text { Primary } \\
\text { occupation }\end{array}$ & 40.7 & 40 & 7 & 0 & 12.3 & 0 \\
\hline $\begin{array}{l}\text { Secondary } \\
\text { occupation }\end{array}$ & 29.4 & 10.7 & 2 & 6.8 & 6.4 & 44.7 \\
\hline
\end{tabular}

About $66 \%$ of Adivasi households had no additional earners except household head (Table 3). Most of the Adivasi households depended on the income of a single person. It was hard to them to lead their family from the income of a single person where CBFFP was promoted as an important strategy to improve their livelihoods.

Table 3. Number of earners in Adivasi households

\begin{tabular}{|c|c|}
\hline No. of earner excluding household heads & Percent (\%) of households ( $=150)$ \\
\hline 3 & 2 \\
\hline 2 & 5.3 \\
\hline 1 & 26.3 \\
\hline No earner & 66.3 \\
\hline
\end{tabular}

\section{Cage based fish fingerling production in ponds}

The average size of ponds in which the cages were installed by Adivasi households, was about $1.2 \pm 1.4$ ha. The larger the pond the better the productivity was evidenced. Adivasi households set their cages in five different pond access arrangements including own ponds, multi-ownership ponds, neighbouring 
ponds, private ponds (lease holder's ponds) and state-owned (khas) ponds. Average number of cages set in each pond was $8 \pm 6.1$. The size of the cages was about $1 \mathrm{~m}^{3}$ with individual construction cost of BDT $400 \pm 85.2$ (USD 5.71 \pm 1.2 ). The stocked fry in the cages to produce fingerlings were of tilapia (Oreochromis niloticus), silver carp (Hypophthalmichthys molitrix), rui (Labeo rohita), mrigal (Cirrhinus cirrhosus), bighead carp (Aristichthys nobilis), common carp (Cyprinus carpio) and Thai sarpunti (Barbonymus gonionotus). The cost of fingerlings per cage varied due to stocking densities, types of species and source of fry. However, average cost of fingerlings was about USD $3.83 \pm 1.8 /$ cage. Most of the Adivasi farmers used rice bran, wheat bran and mustard oil cake as supplementary feed for cage reared fingerlings. Hasan et al. (1985) observed that the supplementary feed containing rice bran (30\%), wheat bran (30\%) and fish meal (40\%) was the best for Nile tilapia (Oreochromis nilotica) production in cages. Most of the farmers supplied feed in the cage one to two times a day early in the morning and late evening. The amount of feed used in one cycle was about 5 to $6 \mathrm{~kg} / \mathrm{cage}$ and the estimated cost was about BDT 100/cycle/cage (USD 1.43/cycle/cage) (Table 4).

Table 4. General characteristics of cage installed in ponds for fingerling production

\begin{tabular}{|l|l|}
\hline Pond/cage characteristics & Value \\
\hline Average area of pond $(\mathrm{ha})$ & $1.2 \pm 1.4$ \\
\hline Average minimum depth of pond $(\mathrm{m})$ & $1.5 \pm 0.9$ \\
\hline Average maximum depth of pond $(\mathrm{m})$ & $3 \pm 0.9$ \\
\hline Average no. of cage set in pond & $8 \pm 6.1$ \\
\hline Average cost of cage construction & BDT 400 $\pm 85.2(\text { USD 5.71 } \pm 1.2)^{\star}$ \\
\hline Average cost of fingerling production & BDT 268 $\pm 129.2 /$ cage (USD 3.83 $\pm 1.8 /$ cage) \\
\hline Amount of feed used & $5-6 \mathrm{~kg} /$ cage \\
\hline Cost of feeding & BDT 100/cycle/cage (USD 1.43/cycle/cage) \\
\hline
\end{tabular}

* 1 USD = BDT 69.93

The fingerling production was dominated $(70 \%)$ by silver carp and tilapia. The amount of fry stocked per cage for first cycle varied from 75 to 2000 fry/cage with an average of 875 fry/cage. During stocking, the average total weight of the fry was $1.5 \mathrm{~kg} / \mathrm{cage}$ and average length was about $3.4 \mathrm{~cm} / \mathrm{fry}$. During second cycle the stocking density varied from 50 to 2000 fry/cage with an average of 889 fry/cage. In the second cycle, the initial average length of the fry was smaller $(2.4 \mathrm{~cm})$ than the first cycle (Table 5).

Table 5. Fry stocking properties of an individual cage

\begin{tabular}{|l|c|c|c|c|c|c|c|c|}
\hline \multirow{2}{*}{ Stocking properties } & \multicolumn{4}{|c|}{$1^{\text {st }}$ cycle } & \multicolumn{4}{c|}{$2^{\text {nd }}$ cycle } \\
\cline { 2 - 10 } & Min & Max & Mean & STDEV & Min & Max & Mean & STDEV \\
\hline Total stocked fry (no/cage) & 75 & 2000 & 875.5 & 507.7 & 50 & 2000 & 889.3 & 462.9 \\
\hline Total stocked fry (kg/cage) & 1 & 4 & 1.6 & 0.6 & 1 & 6 & 1.2 & 1 \\
\hline Length of individual fry (cm) & 1.27 & 6.35 & 3.4 & 1.0 & 1 & 7.6 & 2.4 & 1.8 \\
\hline
\end{tabular}

\section{Fingerling production and its impacts on households}

The average production of fingerlings per cage was about $13 \pm 6.7 \mathrm{~kg}$ while the stocking rate of fry was 1.5 $\mathrm{kg} / \mathrm{cage}$. Out of total production, $9 \mathrm{~kg} / \mathrm{cage}$ was sold, $4 \mathrm{~kg} / \mathrm{cage}$ was consumed and $0.27 \mathrm{~kg} / \mathrm{cage}$ was given away as gift to relatives and neighbours (Fig. 2). The average selling price of the produced fingerlings was about BDT 431 $\pm 509.1 /$ cage/household (USD 6.16 $\pm 7.2 /$ cage/household). 


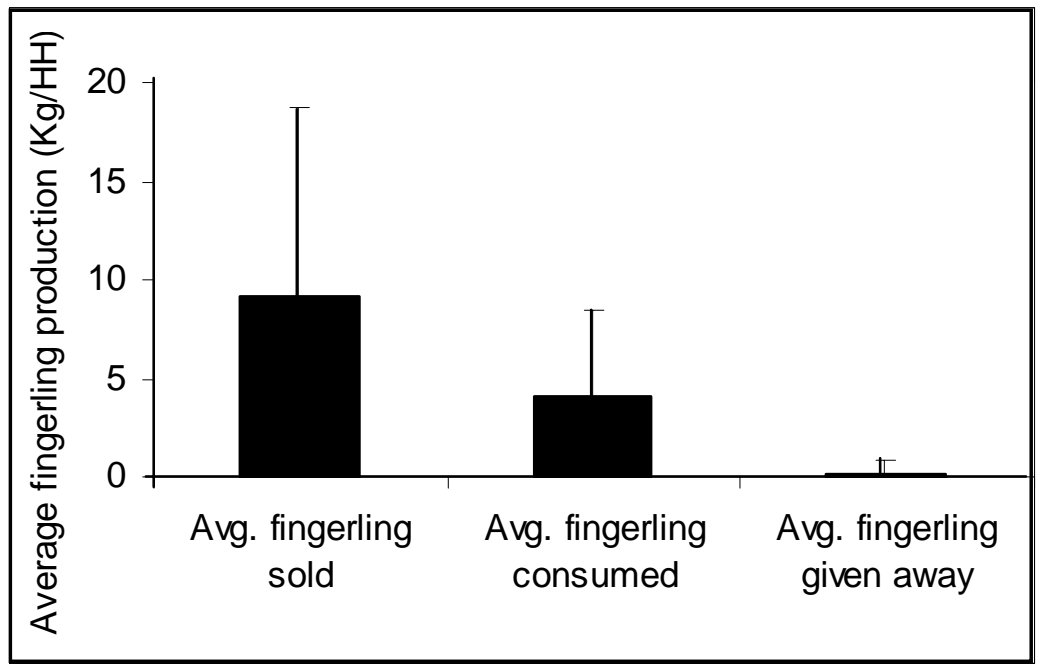

Fig. 2. Use of fish fingerlings produced in CBFFP system (HH-household).

When the size of fingerlings was about 7.62 to $10.16 \mathrm{~cm}$ after 3 months of rearing, farmers harvested them and sold through different marketing channels. The produced fingerlings were mostly sold in local markets however, neighbouring farmers and fry traders also got benefit stocking into their ponds and trading the fingerlings, respectively. Adivasi farmers harvested their fingerlings at different time mainly when the demand of fish seed was high (Fig. 3).

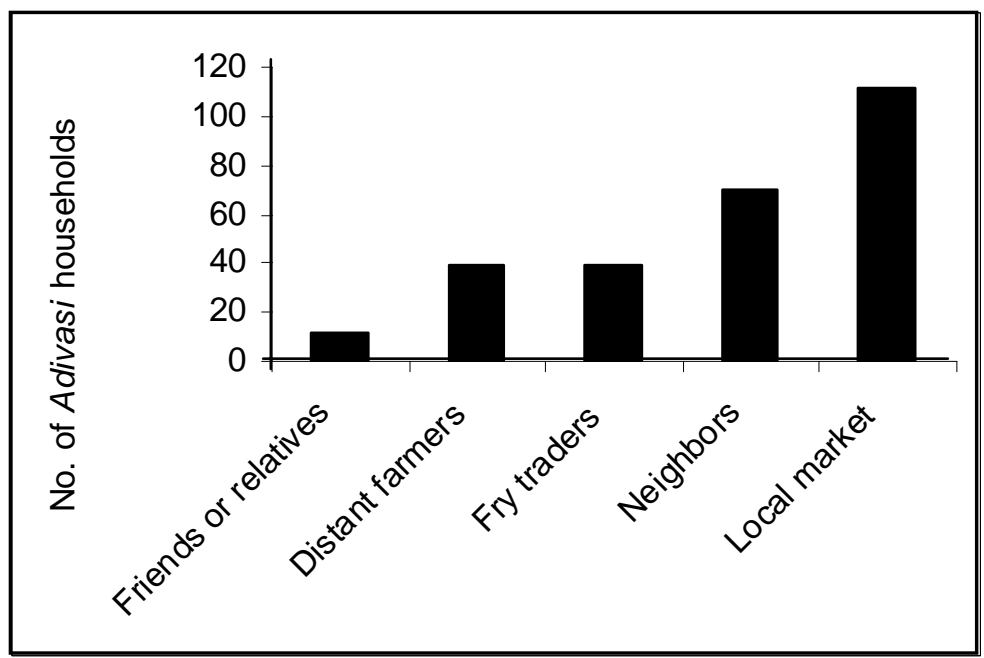

Fig. 3. Fingerlings selling channels used by Adivasi households.

Adivasi's main income was generated selling labour daily in agricultural land. Cage farming contributed about $1.7 \%$ to their total income which was higher than other agricultural activities such as vegetable, jute, maize, wheat, fruit etc. cultivation (Table 6). This indicates that CBFFP can be introduced at Adivasi household level to generate a comparable income. 
Table 6. Sources of income and their distribution in cage farming Adivasi households

\begin{tabular}{|l|r|r|r|c|}
\hline $\begin{array}{l}\text { Income } \\
\text { source }\end{array}$ & $\begin{array}{c}\text { Mean income } \\
\text { (BDT) }\end{array}$ & $\begin{array}{c}\text { Mean income } \\
(\text { USD) }\end{array}$ & $\begin{array}{c}\text { STDVE ( }) \\
\text { BDT (USD) }\end{array}$ & $\begin{array}{c}\text { Percent of the } \\
\text { total income }\end{array}$ \\
\hline Day labour & $16,072.7$ & 229.6 & $17720.2(253.2)$ & 31.4 \\
\hline Rice cultivation & $13,541.3$ & 193.5 & $20799.1(297.1)$ & 26.5 \\
\hline Service & $4,814.0$ & 68.8 & $19994.0(285.6)$ & 9.4 \\
\hline Van pulling & $3,837.3$ & 54.8 & $12913.2(184.5)$ & 7.5 \\
\hline Cattle rearing & $3,085.9$ & 44.1 & $5904.8(84.4)$ & 6.0 \\
\hline Petty business & $2,180.6$ & 31.2 & $8761.1(125.2)$ & 4.3 \\
\hline Poultry rearing & $1,059.9$ & 15.1 & $1818.5(25.9)$ & 2.1 \\
\hline CBFFP & 872.3 & 12.5 & $939.4(13.4)$ & 1.7 \\
\hline Fish selling & 604.0 & 8.6 & $1811.3(25.9)$ & 1.2 \\
\hline Vegetable cultivation & 472.3 & 6.8 & $2031.0(29.0)$ & 0.9 \\
\hline Wheat cultivation & 452.2 & 6.5 & $2582.9(36.9)$ & 0.9 \\
\hline Fruit & 340.9 & 4.9 & $1398.7(19.9)$ & 0.7 \\
\hline Rice collection & 79.3 & 1.1 & $572.7(8.2)$ & 0.2 \\
\hline Jute cultivation & 47.3 & 0.7 & $368.9(5.3)$ & \\
\hline Maize cultivation & 46.7 & 0.7 & $571.5(8.2)$ & 0.1 \\
\hline Shared out land & 40.0 & 0.6 & $489.9(6.9)$ & 0.1 \\
\hline Leased out land & 14.7 & 0.2 & $179.6(2.6)$ & 0.1 \\
\hline Potato cultivation & 14.4 & 0.2 & $176.4(2.5)$ & 0 \\
\hline Fish fry trading (hatchery \\
produced)
\end{tabular}

As part of diverse livelihood benefits, income from cage culture was re-invested in livestock rearing by the Adivasi households. Apart from this, cage culture impacted positively on other aspects of livelihoods such as purchasing food in lean period, saving money, paying credit etc. A substantial proportion of households increased household level fish consumption that they could not catch from the wild sources (Table 7).

\section{Table 7. Household level impacts of cage based fish fingerlings production}

\begin{tabular}{|l|c|c|}
\hline Impacts & Number of households & Percent of households \\
\hline Bought clothing & 2 & 1.3 \\
\hline Bought chicken & 1 & 0.7 \\
\hline Bought duck & 1 & 0.7 \\
\hline Bought chicken and duck & 2 & 1.3 \\
\hline Bought goat & 4 & 2.7 \\
\hline Bought pig & 2 & 1.3 \\
\hline Bought tin for house construction & 1 & 0.7 \\
\hline Bought trees & 1 & 0.7 \\
\hline Increased fish consumption & 47 & 31.3 \\
\hline Constructed toilet facility & 1 & 0.7 \\
\hline General household expenditure & 18 & 12.0 \\
\hline Partial investment for land purpose & 2 & 1.3 \\
\hline Purchased fingerling for stocking own pond & 2 & 1.3 \\
\hline Purchased food (Rice) in lean period (Sep-Oct) & 7 & 4.7 \\
\hline Purchased quality food & 1 & 0.7 \\
\hline Reduced field labouring & 1 & 0.7 \\
\hline Saved money & 16 & 10.7 \\
\hline Spent for agricultural inputs & 3 & 2 \\
\hline Spent for child education & 3 & 2 \\
\hline Paid credit & 4 & 2.7 \\
\hline Could not sell but expected in the following year & 31 & 20.7 \\
\hline
\end{tabular}




\section{Sustainability of CBFFP}

Although there were several positive impacts of CBFFP on Adivasi households however, the sustainability of this technology was constrained by some factors. Poaching of fingerlings from the cage even the whole cage was of the main constraints. This discouraged some households to continue CBFFP. Cage materials especially cage net was not available in the local market from where other interested farmers can purchase and adopt this technology. However, this constraint could be minimized with little support from local upazila extension office of the Department of Fisheries. Finally, as majority of Adivasi households did not have own ponds, accessibility to ponds was found a major hurdle. At the beginning of promotion, the pond owners were not agreed to set the cages in their ponds. They thought that cage culture could affect their pond fish production negatively. This needs a policy level strategy for CBFFP prioritizing access to ponds by Adivasi for aquaculture practices (Haque et al. 2010).

\section{Conclusion}

The cage farming played a considerable role in the uplifting of the socio-economic condition of Adivasi households and it also increased the fish consumption of Adivasi people. From the results of present study, it can be concluded that cage culture could be a complementary option to alleviate the poverty if Adivasi households get access to the pond for CBFFP. Adivasi people are illiterate thus they are far from the mainstream development of the country. At the school level, applied education for agricultural technologies (e.g. aquaculture) with mother tongue could be incorporated. Major problem of cage culture was accessibility to ponds for cage installation. For this, government and other development organizations should have compulsory components in aquaculture extension to mediate pond access arrangement between Adivasi households and large pond owners. In national fisheries policy Adivasi people should be prioritized to leasing the state-owned ponds for CBFFP and associated aquaculture enterprises.

\section{References}

BANBEIS. 2010. Bangladesh Bureau of Educational Information and Statistics. Ministry of Education. Bangladesh.

BBS. 2004. Bangladesh Bureau of Statistics. Statistics Division. Ministry of planning, Government of the People's Republic of Bangladesh, Dhaka. 673 pp.

DoF (Department of Fisheries). 2009. Fishery and Statistical Yearbook of Bangladesh 2007-2008. Fisheries Resources Survey System, Department of Fisheries, Ministry of Fisheries and Livestock, Matshya Bhaban, Dhaka. 42 pp.

DoF (Department of Fisheries). 2010. Fishery and Statistical Yearbook of Bangladesh 2007-2008. Fisheries Resources Survey System, Department of Fisheries, Ministry of Fisheries and Livestock, Matshya Bhaban, Dhaka. 104pp.

Edwards, P. 2000. Aquaculture, poverty impacts and livelihood. Natural Resource Perspective, ODI, Number 56, June 2000.

Hallman, K., Lewis, D.J. and Begum, S. 2003. An Integrated Economic and Social Analysis to Assess the Impact of Vegetable and Fishpond Technologies on Poverty in Rural Bangladesh. Paper No. 163. Washington, D.C: Food Consumption and Nutrition Division Discussion. International Food Policy Research Institute.

Haque, M.M. 2007. Decentralised Fish Seed Network in Northwest Bangladesh: Impacts on Rural Livelihoods. PhD Thesis. Institute of Aquaculture, University of Stirling, UK. 491 pp.

Haque, M.M., Barman, B.K. and Murshed-e-Jahan, K. 2010. Effectiveness of Different Pond Access Arrangements for Cage Based Fish Fingerling Production by Adivasi Households, Policy Brief, The WorldFish Center, Bangladesh. 2 pp.

Hasan, M.R., Haque, A.K.M., Islam, M.A. and Tareque, A.K.M. 1985. Studies on the effect of supplemental feed on the growth of Nile tilapia in cages. Bang. J. Agril. Sci. 12: 37-41.

Kamal, M., Samad, M. and Banu, N. 2003. Santal Community in Bangladesh: Problems and Prospects. Dhaka. 80 pp.

Verdegem, M.C.J., Bosma, R.H. and Verreth, J.A.V. 2006. Reducing Water Use for Animal Production through Aquaculture. Water Resources Development, 22(1): 101-113. 